\title{
An Analysis on the Impact of a Broken Family Towards the Children's Behaviour as Seen in Novel Rainbirds
}

\author{
Novidiana $^{1)}$, Ahmad Muhid ${ }^{2}$, Didit Kurniadi ${ }^{3)}$ \\ Faculty of Language and Culture, University of AKI \\ email: novidiana99@gmail.com
}

\begin{abstract}
In this article, the topic is about the impact from a broken family towards the children behaviour base on the novel Rainbirds. This issue is fascinating to be discussed because the awareness about bad impact that might occur to children because of their family problem is happening yet very rare being discussed. The fact that there are so many children lived in a condition of bad environment and broken family is undeniable. Ren Ishida and Rio Nakajima struggled with their life because of their family background. Based on the story, the goal of this research is to analyse it under the title "An Analysis on The Impact of A Broken Family Towards The Children's Behaviour as Seen in Novel: Rainbirds".

In the analysis, there are two methods of research; firstly, library research then taking opinion from experts to support the idea. To get the data, structural approach is used because the discussion is about the structure of story such as character and characterization. It uses the theory of B.F Skinner about behaviourism and Sigmund Freud about Id, Ego and Superego to analyse deeply about the behaviour of the characters and find out about their personality that leads to their actions.

From the discussion, based on the psychology theory mentioned, Ren Ishida is mostly superego type of person because he often does something good although he was id-driven caused from his childhood experience in his family. Rio Nakajima on the other hand, is mostly id-driven, she tends to do action as she please without realizing the impact of her action towards herself. Each character has their struggle. Each character is battling with their problem and reacts in a different ways. This story is very interesting because through the story we can learn more about the struggle children will endure if they have a broken family and how that problem impacts their life.
\end{abstract}

Keywords: behaviour, broken family, children, rainbirds

\section{Introduction}

Literature reflects the life of human beings in all aspects such as ideas, expression, passions, struggles, etc through several forms in literary works. Since literature is reflecting the real event in human's life, it helps us to relate more to the literature and increase our knowledge about human problems including culture, moral, habit, and human interest. Literature is a creative activity and art without artistic values literature would be just another kind of writing along with scientific, works, reports, etc. It can help them comprehend 
other people's conditions and qualities. Therefore, literature can help human to understand more about life in general and help them growth personally and intellectually.

Novel is one of literary works which is mostly defined as reflection of real life that is written in the form of a book. Novel contains many aspects of human's life also talks and describe what happen in surrounding. This novel is talking about a young man named Ren Ishida who were trapped in a situation where the only closest person to him, his sister Keiko Ishida, was murdered. This unfortunate event made him travel from his home in Tokyo to a small town called Akakawa which is the place his beloved sister was killed. His journey begin with full thoughts of wondering what is happened and who would killed his sister. The case remind unsolved and that is why Ren needed to stay longer in Akakawa to cooperate with the local police in his sister's case.

Mystery after mystery behind his sister's death is indirectly driving him even more into his late sister's life in Akakawa. Starting with the place where his sister Keiko used to worked which happen to be offering him his sister's position as a teacher in an educational program institute named Yotsuba. In this place, he met a young student named Rio Nakajima and suddenly Ren got his eyes on this young girl. Rio is known as one of a trouble student from a broken family who were often missing classes, pick-pocketing in a store, smoke, and she appeared to be a really introvert person with no friends. The relation between Ren and Rio grew over time but little did he know, Rio is the key of all question he had.

Struggles of Rio Nakajima's is interesting to review because of the trouble character that she had which is coming from a broken family background. This issue is really exciting to analyse too especially in today's society when the effect of a broken family to the children often being forgotten. In order to limit the discussion of this research, the scope is to analyse the choosing of a topic impact of a broken family to children's behaviour. This research iss done by analysing the words or sentences in the novel which considered as possible behaviour that often happen to children with a family problem.

In this research, the method of data collection is used. In this documentation technique method, Sugiyono (2013: 240) also states that: “dokumen merupakan catatan peristiwa yang sudah berlalu. Dokumen bisa berbentuk tulisan, gambar, atau karya-karya monumental dari 
Jurnal CULTURE (Culture, Language, and Literature Review), 8(1), Mei 2021, 77-88

Copyright (ङ) 2021, Jurnal CULTURE (Culture, Language, and Literature Review), e-ISSN 2775-4618, p-ISSN 2355-8660

seseorang. Dokumen yang berbentuk karya misalnya karya seni yang dapat berupa gambar, patung, film, dan lain-lain"

After all of the data are collected, we began to make analysis of the data. Analysing data has a purpose to limit the data in a research. In this method, we used qualitative method to analyse the problem. This method of qualitative of analysis is used to do research about the impact of a broken family towards the children's behaviour as seen in novel RAINBIRDS

\section{Review of Related Literature}

Novel was originally developed in the form of narrative such as biography and letters which is basically a nonfiction written works. Sumardjo (1998) states that "novel is a story with the prose form in long shape, this long shape means the story, including the complex plot, many characters and various settings". As the time passed, novel has evolved into not only a nonfiction written works but it also refers to a fiction written works which can be interpreted by the authors according to their imagination. Most of novels are concerned with the ordinary people and their problems in the societies in which they find themselves. Novel can reveal the social reality in life (Asriani, 2016).

Novel is usually a long narrative which describe fictional events and characters in a form of a story. A novel may have a complex themes, many characters of various atmospheres and story line according to the author imagination. (Holman and Harmon, 1986) while literature itself often said to be school of lives that author made conduct individual in society. Authors often point out what they found important about human to propose the ideal alternative way thing actually custom and more about particular social group or individuals. Their idea and value are explored and exposed, (Taylor, 1981). Novel can be divided in three themes, they are Romantic novel, fantasy novel and adventure novel.

There are two elements in novel called intrinsic elements and extrinsic elements. Intrinsic elements is a part in the novel. Meanwhile, novel need elements so that a story can be build and becomes a sequence of prose. The intrinsic elements in the novel are character and theme. A literary work is not enough and will not complete without a character. Character is the key or the basic elements of a story so that it takes great attention to study about. Character is so important in a story and it has a great impact. However, analyzing a character is more difficult to analyse because character is so complex. Character can be describe as a person, things, animals, or any 
entity whose existence can be found in a story (Croft, 2002). The major character is divided into two, protagonist and antagonist. Since there are so many meaning offered in a story, theme need to be more specific and is the most special meaning among all. Theme is the idea of common bases that is sustaining a work of literature and are contained in the structure regarding commonality or differences (Hartoko and Rahmanto, 1986). Theme in general is the main idea or expression of the writers that they wanted to share to the readers. Theme is also can be describe as the underlying meaning of a story which contains the center idea of all literary work.

Extrinsic elements are the elements outside the literary works. It is not directly affect the structure or system in the literature. Extrinsic elements consist of individual subjectivity from the author's state that consist beliefs, attitudes, or view that affecting the literary work itself. In addition, intrinsic elements related to psychology of the authors and their values such as religion, politics, culture, economy and so on. Talking about psychology, people are not used to disregarding the unforgettable name of Sigmund Freud who was the founder of psychoanalysis. The goal of psychoanalysis is to strengthen ego, to make it more independent than superego, to extend the perception, to escalate its organization which have fresher parts than id (Setyorini, 2017). Freud was not only a physician, but also neurologist as well. Psychoanalysis is both a system of psychology and concerning personality, Freud held that it is made up of three major systems: the id, the ego and the superego.

\subsection{Id}

The Id is the unorganized part of the personality structure which contains the basic drives. The Id contains the libido, which is the primary source of instinctual force that is unresponsive to the demands of reality. The Id acts according to the pleasure principle, seek to avoid pain or displeasure aroused by increases in instinctual tension. In the Id, contrary impulses exist side by side, without cancelling each other out. There is nothing in the Id that could be compared with negation nothing in the Id which corresponds to the idea of time.

Developmentally, the Id precedes the Ego; i.e. the psychic apparatus begins, at birth, as an undifferentiated Id, part of which then develops into a structured Ego. The mind of a newborn child is regarded as completely "Idridden", in the sense that is a mass of instinctive drives and impulses, and needs immediate satisfaction, a view which equates a newborn child with an Idridden individual. 
Jurnal CULTURE (Culture, Language, and Literature Review), 8(1), Mei 2021, 77-88

Copyright () 2021, Jurnal CULTURE (Culture, Language, and Literature Review), e-ISSN 2775-4618, p-ISSN 2355-8660

The Id is responsible for our basic drives, "knows no judgments of value: no good and evil, no morality. Instinctual cathexes seeking discharge - that, in our view, is all there is in the Id." It is regarded as "the great reservoir of libido", the instinctive drive to create - the life instinct that are crucial to pleasurable survival

\subsection{Ego}

The ego acts, according to the reality principle, seek to the please the Id's drive in realistic ways that will benefit in the long term rather than bringing grief. At the same time, Freud concedes that as the ego "attempts to mediate between Id and reality, it is often obliged to cloak the Ucs (Unconscious) command of the Id with its own Pcs (Preconscious) rationalization, to conceal the Id's conflicts with reality, to profess to be taking notice of reality even when the Id has remained rigid and unyielding."

The Ego comprises the organized part of the personality structure that includes defensive, perceptual, intellectual-cognitive, and executive functions. Conscious awareness resides in the Ego, although not all of the operations of the Ego are conscious. Originally, Freud used the word ego to mean a sense of self, but later revised it to mean a set of psychic functions such as judgment, tolerance, reality testing, control, planning, defence, synthesis of information, intellectual functioning, and memory.

The Ego separates out what is real. It helps us organize our thoughts and make sense of them and the world around us. The Ego is that part of the Id which has been modified by the direct influence of the external world. The Ego represents what may be called reason and common sense, in contrast to the Id, which contains the passion. Thus the Ego, driven by the Id, confined by the super-ego, repulsed by reality, struggles in bringing about harmony among the forces and influences working in and upon Id, and readily "breaks out the anxiety - realistic anxiety regarding the external world, moral anxiety regarding the Super-ego, and neurotic anxiety regarding the strength of the passion in the Id.

It has to do its best to suit all three, thus is constantly feeling hemmed by the danger of causing discontent on two other side. It is said, however, that the Ego seems to be more loyal to the Id, preferring to gloss over the finer details of reality to minimize conflicts while pretending to have a regard for reality. But the Super-ego is constantly watching every one of the Ego's moves and punishes it with feeling of guilt, anxiety and inferiority. 
To overcome this the Ego employs defence mechanism. The defence mechanism are not done so directly or consciously. They lessen the tension by covering up our impulses that are threatening. The Ego defence mechanism are often used by the ego when the Id behaviour conflicts with reality and either society's moral, norms and taboos or the individual's expectations as a result of the internalization of these morals, norms and their taboos.

In modern English, Ego has many meanings. It could mean one's self-esteem, an inflated sense of self-worth, or in philosophical terms, one's self. Ego development is known as the developments of multiple processes, cognitive function, defense and interpersonal skills or to early adolescence when ego processes are emerged.

\subsection{Superego}

Freud developed his concept of the Super-ego from and earlier combination of the Ego ideal and the special psychical agency which performs the task of seeing that narcissistic satisfaction from the Ego ideal is ensured what we call our 'conscience'. For him the installation of the Super-ego can be described as a successful instance of identification with the parental agency, while as development proceeds the Super-ego also takes on the influence of those who have stepped into the place of parents - educators, teachers, and people chosen as ideal models.

The Super-ego aims for perfection. It comprises that organized part of the personality structure, mainly but not entirely unconscious, that includes the individual's ego ideals, spiritual goal, and the psychic agency (commonly called "conscience") that criticizes and prohibits his or her drives, fantasies, feelings and actions. The Super-ego can be thought of as a type of conscience that punishes misbehaviour with feelings of guilt. For example, for having extra-marital affairs. The Super-ego works in contradiction to the Id.

The Super-ego strives to act in a socially appropriate manner, whereas the Id just wants instant self-gratification. The Super-ego controls our sense of right and wrong and guilt. It helps us fit into society by getting us to act in socially acceptable ways. The Super-ego's demands often oppose the Id's, so the Ego sometimes has a hard time in reconciling the two. Freud's theory implies that the Super-ego is a symbolic internalization of the father figure and cultural regulations. The Super-ego tends to stand in opposition the desires of the Id because of their conflicting objectives, and its aggressiveness towards the Ego.

The Super-ego acts as the conscience, maintaining our sense of morality and proscription from taboos. The Super-ego and the Ego are the product of two key factors: the state of 
Jurnal CULTURE (Culture, Language, and Literature Review), 8(1), Mei 2021, 77-88

Copyright $\odot$ 2021, Jurnal CULTURE (Culture, Language, and Literature Review), e-ISSN 2775-4618, p-ISSN 2355-8660

helplessness of the child and the Oedipus complex. Its formation takes place during the dissolution of the Oedipus complex and is formed by an identification with and internalization of the father figure after the little boy can't successfully hold the mother as a love-object out of fear of castration.

\section{Method of Research}

\subsection{Method of Data Collection}

Method of data collection is important to make an academic writing as Sugiyono (2013:2) states: "teknik pengumpulan data merupakan langkah yang paling strategis dalam penelitian karena tujuan utama penelitian adalah mendapatkan data".

In this research, the researchers use documentation technique as the method of data collection. In this documentation technique method, Sugiyono (2013:240) states that:

"dokumen merupakan catatan perostiwa yang sudah berlalu. Dokumen bisa berbentuk tulisan, gambar, atau karya-karya monumental dari seseorang. Dokumen yang berbentuk karya misalnya karya seni yang dapat berupa gambar, patung, film, dan lain-lain"

This method is a method of collecting data based on a novel.

\subsection{Method of Data Analysis}

After all of the data are collected, the writer begins to make analysis of the data. Analyzing data has a purpose to limit the data that will be analyzed in a research. In this method, the writers use qualitative method to analyze the problem. This method of qualitative of analysis is used to do research about the impact of a broken family towards the children's behaviour as seen in novel "Rainbirds"

\section{Discussion}

There are two main characters from Rainbirds novel, Ren Ishida and Rio Nakajima. All is about the characters' personality and how their broken family's background is impacting the two different persons in a different way. The novel also implies the outcome of each personality caused by their family problem and how it affects their social life. The data used based on the story line from Rainbirds novel.

In most cases, problem behaviour of most children is starting from their problematic family's background. This background has an impact on their personal and social life. It means 
that a person's personality has a strong relation with their life. Whether it is their personal life or their social life, the two elements are related. The characters of Ren Ishida and Rio Nakajima are as the source of this research. The two characters are the perfect example to explain how the life of children with a broken family's background is, alongside the outcome characteristic of the character based on Rainbirds novel.

\subsection{The Family's Problem of Ren Ishida}

Growing up, Ren Ishida has never seen his parents showing affection neither love to one another later or cares about Ren and Keiko his sister as all parents should do. As a child, Ren does not understand much and used to the situation where his parents hated each other so much. Up to the point where Ren thought the hates, the fights, and yelling are something normal in his family.

"Our parents were hardly at home, they refused to deal with each other or their failing marriage" (Goenawan, 2018: 14).

Clearly in this situation, Ren knows exactly how things are never good between his parents and that his family surely is not a happy family. Growing up knowing that his parents have no love towards one another is not easy. Children are supposed to learn everything from their family, especially from their parents. Emotions like love, affection, attention, and other important lessons are things children are supposed to get and learn from their parents.

Unfortunately for Ren, those things are something he can never learn later on from his parents, because all he knows and learns are hatred. Ren watches his parents fighting every single day, and refuses to deal with one another. By that, he understands that his parents and his family are broken. For children to feel that the family does not work as it should be and is different from other family must be really hard. The feeling of jealousy, where other family seems more perfect is something children should never endure. This thoughts and feelings are something that later on can affect children mentally.

"Things got worse. Both of them avoided home. Father often returned passed midnight, staggering in reeking of alcohol and sweat. Mother spent her time playing mahjong or singing karaoke at her friend's place. On the rare occasion when both of them were home, they shouted at each other and threw things" (Goenawan, 2018:16).

Living in that kind of condition where anything he sees and learns are hates, anger, parents who were constantly fighting, surely impacted Ren's character as a child. Lucky for Ren, he has a sister who loves him so much and therefore he can understand how to love and care about other people, a sister who is also a parent to him. In a condition where parents are not interested in their 
children and pay no attention or showing any affection, it is so important for children to have someone whom they can rely on and look up to.

Ren is so fortunate to have his sister by his side and support him. Ren and his sister takes care and stands for each other as describes in the novel. This is also one of the reasons these children can survive from their broken family. Although their parents are not the best parents they could have asked for, Ren and his sister Keiko can survive by loving and cares for each other to remain strong.

“Don't cry' she said, 'I will cook you something” (Goenawan, 2018: 18).

The two siblings care so much about each other and even though Ren has lack of attention and love from his parents, he still has his sister by his side because children need love and cares. In a condition where parents cannot provide their children with love and care as they should, Ren sister's role plays a very important part in his upbringing because as a child, Ren still can feel that he is loved and that there is still someone who cares about him.

\subsection{The Family's Problem of Rio Nakajima}

Things are a little bit different in Rio Nakajima's case. Rio was raised in a happy family with a very supportive environment where she used to see how her parents love each other so much and showered her with all the love until she witnesses their family has falling apart before her eyes. In a split of second, her perfect family and her life has crumbled. Young Rio does not understand what is happening to her family. All of the sudden, her parents are no longer together and her mother has already left, leaving Rio and her father, devastated and completely broken.

"She won't be back any time soon. She ran away from home a few weeks ago. Abandoned my father and me" (Goenawan, 2018:113).

It is never easy for children to see their parents fighting especially when everything is used to be alright, bright and happy. Not only Rio has to accept the fact that her family is not the same anymore, she also needs to cope with her lost after her mother left her. Things go downhill for Rio because not only she lost her mother, but she also has to live with her father which is the person who has turned their family upside down. Rio hates her father so much and blames him for everything that has happening to her and their family. For Rio, her life is over the moment her mother left their home.

For a child to carry that kind of burden is something unimaginable. Losing their family and their parents at the same time can cause a huge damage to children. We can take an example from 
Rio's character in the novel. Adults especially parents, should be aware about this issues. Parents supposedly understand that their children are the number one target if any problems in their family encountered. But unfortunately, parents often forget that it is their responsibility to keep their family united, and the fact that children should be their only priority. Arguments and egos are way bigger that parents can no longer see their children as something important.

"You are having an affair with my sister" (Goenawan, 2018:278)

In the story, it turns out Rio's father is having an affair with Ren's sister. The affair leads to something bigger and causes their family to crumble. Rio has nowhere to turn, she is the only child. In one hand, her mother's disappearance already hits her very hard but in the other hand she is now has to live with the person who ruined her life which is her father. This condition has affected Rio hard and she starts to distance herself from her social life especially her father.

"I'm more concerned with how well she gets along with her peers. She never talks about school and I never see any of her friends. A girl her age should be socializing a lot, shouldn't she? Having sleep over and things like that" (Goenawan, 2018:111).

Since Rio has no one to turn to, she starts to become a lonely person and distances herself not only with her father but also people. The relation between father and daughter has become complicated. In one hand, her father is the only thing Rio have, but in the other hand her father also the reason behind all of her problems. Things are tough after her mother has left and it is getting worse for young Rio. The feeling of being betrayed, confuse, all the hatred and anger has concurred Rio and it leads to her changing personality. These things are what triggered Rio and change her behaviour.

"My sister is dead, and that makes your wife a murderer. That's the truth" (Goenawan, 2018:282)

Rio is struggling not only with the fact that her family is now falling apart and her mother has left her alone, but also the fact that her mother also becomes a possible suspect of a murder. This situation is clearly the darkest point in the life of this young girl. This family's problem smashes her hard and it has changed her life entirely.

\section{Conclusion}

From the novel of Rainbirds, it can be clearly seen the struggle of Ren Ishida and Rio Nakajima as children who were raised into a broken family. Family is a really important and crucial environment for children but people often forget this part. It plays a surely important role in 
building the children's character. The very first social interaction children have is their family and it is supposed to be the safest place to the children. Unfortunately, family has become a boomerang for Ren Ishida and Rio Nakajima.

Ren Ishida has never experienced love from his parents. Since he can remember, what he only knows is his parent's constant fight. When a home never feels like home, children do not have other places to go. In Ren Ishida's case, all of his problems he keeps by himself and he is used to a condition where he is forced to hold back everything. He never has a chance to speak, never even has the chance to deliver his thoughts. This situation then builds up his character and limits his ability in many aspects. Ren Ishida does not have dreams or purposes in life, in other word he just lives his life without knowing what to do or to achieve.

Rio Nakajima is not any different from Ren Ishida. Her problems at home have formed her character into the worst. Children cope with their problems in so many ways but in Rio's case, her problems make her do all the bad things possible. Just like what Skinner explains in his book "About Behaviourism" He said feelings that occur cause by behaviour meaning that someone's behaviour can be caused by a stimulus response which leads to an action. The stimulus taken by the characters make a change to heir behaviour that can be observed in reality from behaviourism perspective of B.F Skinner. From that, the environment result a response from their behaviour wheter it is positive or negative (Fibiani, 2020). The stimulus response of Rio leads to an action where she has become a trouble maker. She smokes, shops lifting, skips classes, and many more.

Not only her character, but her personality is also impacted. Rio does not have friends and she has isolated herself. She has become a very introvert person and never wants to talk to anybody including her father. A family that is falling apart is never easy to accept especially for children. It can change the children's personality and character all at once just like in Rio's case. Ren Ishida and Rio Nakajima are the examples and also proofs that broken family is related to the outcome of children's character.

Based on the two characters we can learn that children from a broken family are badly impacted because of that. Ren Ishida who was born and raised into a broken family with a constant fight, and Rio Nakajima who once had a happy family but then the family is falling apart right. These two kinds of family problems are seemingly different but have the same result and impact to the children. 


\section{References}

Asriani, Lia. (2016). Masalah-Masalah Sosial dalam Novel dari Subuh Hingga Malam: Perjalanan Seorang Putra Minang Mencari Jalan Kebenaran Karya Abdul Wadud Karim Amrullah. Jurnal Bastra (Bahasa dan Sastra), 1 (1), 18-36. DOI: http://dx.doi.org/10.36709/jb.v1i01.1052.

Croft, Steven. (2002). Revise GCSE Study Guide: English/English Literature (Revise GCSE Study Guide). Letts Educational.

Holman, Clarence Hugh., \& Harmon, William. (1986). A Handbook to Literature. Macmillan.

Fibiani, Mufadila., \& Saraswati, Ekarini. (2020). Perubahan Tingkah Laku Tokoh Saya dalam Novel "Jangan Sisakan Nasi dalam Piring” Karya Kembangmanggis: Perspektif Behaviourisme Skinner. Belajar Bahasa, Jurnal Program Ilmiah Pendidikan Bahasa \& Sastra Indonesia, 5 (2), 199-210. DOI: https://doi.org/10.32528/bb.v5i2.3273.

Goenawan, Clarissa. (2018). Rainbirds. Soho Press Inc.

Hartoko, Dick., \& B. Rahmanto. (1986). Pemandu di Dunia Sastra. Kanisius.

Setyorini, Ririn. (2017). Analisis Kepribadian Tokoh Marni Kajian Psikologi Sigmund Freud dalam Novel Entrok Karya Okky Madasari. Kajian Linguistik dan Sastra, 2 (1), 12-24. DOI: https://doi.org/10.23917/k1s.v2i1.5348.

Sugiyono. (2013). Metode Penelitian Kuantitatif, Kualitatif dan R\&D. Alfabeta. CV.

Sumardjo, Jakob., \& Saini K.M. (1998). Apresiasi Kesusastraan. PT. Gramedia.

Taylor, Richard. (1981). Understanding the Elements of Literature: Its Forms, Technique, and Cultural Conventions. St. Martin's Press. 